\title{
Quality of Life, Anxiety and Depression in Patients with Differentiated Thyroid Cancer under Short Term Hypothyroidism Induced by Levothyroxine Withdrawal
}

\author{
Kvalita života, úzkost a deprese u pacientů s diferencovaným \\ karcinomem štítné žlázy během krátkodobé hypotyreózy \\ indukované vysazením levothyroxinu
}

\author{
Badihian S. ${ }^{1}$, Jalalpour P. ${ }^{1}$, Mirdamadi M. ${ }^{2}$, Moslehi M. ${ }^{2}$ \\ 'Students' Research Center, School of Medicine, Isfahan University of Medical Sciences, Isfahan, Iran \\ ${ }^{2}$ Department of Medical Physics and Biomedical Engineering, School of Medicine, Isfahan University of Medical Sciences, Isfahan, Iran
}

\begin{abstract}
Summary
Background: We studied quality of life (QOL), anxiety, and depression in patients with differentiated thyroid cancer (DTC) either during treatment with levothyroxine or during withdrawal from levothyroxine when whole-body scanning (WBS) needed to be performed. Methods: DTC patients projected to undergo WBS were included in the study. They were studied at two time-points - the day before levothyroxine withdrawal, and one month after levothyroxine withdrawal. They were asked to fill WHOQOL-Bref, BDI-II, and HADS questionnaires at both time-points, and blood samples were taken to measure TSH, Tg, and TgAb levels. Results: Twenty-nine subjects (11 males) with a mean age of $42.6 \pm 14.1$ years entered the study. From the first to second time-point, the mean TSH level increased from 0.73 to $106.9 \mathrm{U} / \mathrm{ml}$ and the mean Tg level increased from 20.4 to $63.6 \mathrm{ng} / \mathrm{ml}$. QOL scores decreased in four dimensions (physical health: 67.8 to 25.7 ; psychological: 58.9 to 38.9 ; social relationship: 67.5 to 56 ; and environment: 57.2 to 48.8 ). Patients also felt more depressed (48.3\% to $93.2 \%)$ and anxious (65.5\% to $89.6 \%)$. All changes were statistically significant $(p<0.005)$. Conclusion: We found decreased $\mathrm{QOL}$ after short-term hypothyroidism, especially in physical health and psychological dimensions. We also found that patients became significantly depressed and anxious after levothyroxine withdrawal. Our findings suggest that alternative therapies, such as those employing rhTSH, should be considered for these patients. Psycho-oncological support might also be useful in helping them overcome their symptoms during short-term hypothyroidism; however, considering the reversibility of their symptoms, supportive care might be more effective.
\end{abstract}

Key words

quality of life - anxiety - depression - thyroid cancer - hypothyroidism - levothyroxine - whole body scanning
This work was funded by vice-chancellor for research of Isfahan University of Medical Sciences (grant No. 190155).

Tato práce byla podpořena grantem prorektora pro vědu Univerzity pro lékařské vědy v Isfahanu č. 190155 ,

The authors declare they have no potential conflicts of interest concerning drugs, products, or services used in the study.

Autor̆i deklarují, že $v$ souvislosti s předmětem studie nemaji žádné komerční zájmy.

The Editorial Board declares that the manuscript met the ICMJE recommendation for biomedical papers.

Redakční rada potvrzuje, že rukopis práce splnil ICMJE kritéria pro publikace zasílané do biomedicínských časopisů.

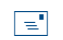

Masoud Moslehi, MD Department of Medical Physics and Biomedical Engineering School of Medicine Isfahan University of Medical Sciences P.O. Box 319

Hezar-Jerib Avenue

Isfahan, Iran

e-mail:mmoslehi_m@yahoo.com

Submitted/Obdrženo: 5. 5. 2016

Accepted/Přijato: 21. 6. 2016

http://dx.doi.org/10.14735/amko2016439 


\begin{abstract}
Souhrn
Východiska: Sledovali jsme kvalitu života (quality of life - QOL), výskyt úzkosti a deprese u pacientů s diferencovaným karcinomem štítné žlázy jak během léčby levothyroxinem, tak při jeho vysazení potřebném při celotělové scintigrafii (whole-body scanning -WBS). Metody: Do studie byli zařazeni pacienti s diferencovaným karcinomem štítné žlázy, kteří měli podstoupit WBS. Byli vyšetřováni ve dvou časových bodech - den před a měsíc po vysazení levothyroxinu. Pacienti vyplnili v obou časových bodech dotazníky WHOQOL-BREF, BDI-II a HADS. Byly odebrány vzorky krve ke stanovení hladin TSH, Tg a TgAb. Výsledky: Do studie bylo zařazeno 29 subjektů (11 mužů) průměrného věku 42,6 $\pm 14,1$ let. Od prvního do druhého časového bodu se hladiny TSH zvýšily 0,73 na 106,9 U/ml a u Tg se průměrné hladiny zvýšily z 20,4 na 63,6 ng/ml. QOL skóre bylo kleslo ve čtyřech ukazatelích (fyzické zdraví: z 67,8 na 25,7; psychologické: $z$ 58,9 na 38,9; sociální vztahy: $z$ 67,5 na 56; prostředí: z 57,2 na 48,8). Pacienti také pocitovali větší depresi (ze 48,3 na 93,2 \%) a úzkost (ze 65,5 na 89,6 \%). Všechny změny byly statisticky významné ( $p<0,005)$. Závěr: Zjistili jsme po krátkodobé hypotyreóze snížení QOL, zejména v ukazatelích fyzického zdraví a psychologické kondice. Také jsme zjistili výrazné zvýšení depresí a úzkosti po vysazení levothyroxinu. Naše nálezy podporují u těchto pacientů využití jiných metod léčby, které využívají rhTSH. V průběhu krátkodobé hypotyreózy může být užitečná k překonání př́znaků i psychoonkologická podpora. Nicméně s ohledem na reverzibilitu symptomů může být účinnější prostá podpưrná péče.
\end{abstract}

\title{
Klíčová slova
}

kvalita života - úzkost - deprese - nádor štítné žlázy - hypothyroidizmus - vysazení levothyroxinu - celotělová scintigrafie

\section{Introduction}

Thyroid cancer is the most frequent endocrine malignancy standing as the $12^{\text {th }}$ cancer in males and $9^{\text {th }}$ cancer in females in Iran [1]. Differentiated thyroid cancer (DTC), arising from thyroid follicular epithelial cells, is a slowly growing disease and accounts for a vast majority of thyroid cancers [2]. This malignancy has an incidence rate of 0.5 to 10 per 10,000 individuals. Prognosis is good, and only $0.3 \%$ of all cancer deaths are related to thyroid cancer [3]. In contrast to more common malignancies, DTC is known for its slow clinical course and potential for late relapses, and lifelong follow-up is required [4].

Standard management of DTC is total thyroidectomy, if necessary with cervical lymph node dissection, followed by radioiodine ablation (with some exceptions) $[2,4,5]$. Then, patients need to be treated with levothyroxine for life which eliminates symptoms of hypothyroidism and suppresses thyrotropin (TSH) levels [2].

To detect and ablate thyroid remnants using radioactive iodine, stimulation by TSH is required. Therefore, levothyroxine is discontinued in these patients before whole body scanning (WBS) to increase TSH levels [2]. Levothyroxine withdrawal causes a short-term hypothyroidism in these patients and compels symptoms such as fatigue, decreased appetite, fluid retention and constipation [6,7]. Besides, previous findings have shown that these episodes of hypothyroidism have noticeable negative effects on patients' quality of life (QOL) and their psychometric functionality $[8,9]$.

In the long-term management of cancer, it is important to preserve health-related quality of life (HRQOL) in patients in addition to increasing their survival [10]. HRQOL is decreased in these patients not only because of the episodes of levothyroxine withdrawal, but also because of the administration of supraphysiological doses of levothyroxine [8-10]. Some studies suggest psychological treatments for cancer patients [11,12]; however, it has been condoned in DTC patients probably because of low mortality and morbidity rates [13].

Previous studies have focused mostly on evaluation of HRQOL in DTC patients $[10,14-17]$, and only few studies have noticed other psychological aspects in these patients $[9,18]$. Also, alterations in $\mathrm{QOL}$, anxiety and depression are not studied in short-term hypothyroidism. In this study, we aimed to evaluate $\mathrm{HRQOL}$, anxiety and depression in these patients.

\section{Patients and methods}

This is an observational study conducted from 2012 to 2015 at Seyed-Al-Shohada hospital affiliated to Isfahan University of Medical Sciences, located in the city of Isfahan, Iran. The inclusion criteria were defined as known DTC patients with initial thyroidectomy and radioactive iodine ablation who were referred for routine WBS during their follow-up during the study. The exclusion criteria were: age < 16 years old; presence of known psychiatric disease, mental illness or brain injury; known chronic comorbidities; taking psychiatric medication. The exclusion criteria were defined in order to eliminate the probable effect of mentioned conditions on psychological parameters. The study was approved by regional bioethics committee of Isfahan University of Medical Sciences, and all patients were asked to fill an informed consent form.

Patients were studied during levothyroxine withdrawal at two time points within one month - the last day on levothyroxine at their usual suppressive doses, and the day before administration of radioactive iodine for WBS. We expected to see a euthyroid or subclinical or mild hyperthyroid status in our cases at the first time point, changing to hypothyroidism at the second time point. To confirm these expectations, we took blood sample from patients at both time points to check TSH levels. Also, Tg (thyroglobuline) and $\mathrm{TgAb}$ (thyroglobuline antibody) were measured at both time points to find out any residual thyroid tissue. The dosage of levothyroxine during follow-up and the indication for WBS were decided by the physicians referring patients. At the time of study, recombinant human TSH was not available in our department of nuclear medicine.

All patients were advised to take their usual levothyroxine dose at the first time point and levothyroxine was withdrawn thereafter. Blood samples were 
Tab. 1. Result from blood tests in patients before and after levothyroxine withdrawal.

\begin{tabular}{|c|c|c|c|c|c|c|}
\hline & \multicolumn{2}{|c|}{ TSH (U/ml) } & \multicolumn{2}{|c|}{$\operatorname{TgAb}(\mathrm{U} / \mathrm{ml})$} & \multicolumn{2}{|c|}{$\mathrm{Tg}(\mathrm{ng} / \mathrm{ml})$} \\
\hline & before & after & before & after & before & after \\
\hline mean (SD) & $0.73(0.91)$ & $106.9(57.7)$ & 32.3 (113.7) & $33.2(104.1)$ & $20.4(49.5)$ & $63.6(102.4)$ \\
\hline range & $0-3$ & $32-276$ & $2.0-620$ & $2.0-569$ & $0-254$ & $0.2-500$ \\
\hline $\begin{array}{l}\mathrm{p} \text { (comparison of items before } \\
\text { and after levothyroxine withdrawal) }\end{array}$ & \multicolumn{2}{|c|}{$\mathrm{p}<0.001$} & \multicolumn{2}{|c|}{$\mathrm{p}<0.001$} & \multicolumn{2}{|c|}{$p>0.05$} \\
\hline
\end{tabular}

Tab. 2. Comparison of WHOQOL scores before and after levothyroxine withdrawal.

\begin{tabular}{|c|c|c|c|c|c|c|c|c|c|c|}
\hline & \multicolumn{2}{|c|}{ Dimension $1^{1}$} & \multicolumn{2}{|c|}{ Dimension $2^{2}$} & \multicolumn{2}{|c|}{ Dimension $3^{3}$} & \multicolumn{2}{|c|}{ Dimension $4^{4}$} & \multicolumn{2}{|c|}{ Total score } \\
\hline & before & after & before & after & before & after & before & after & before & after \\
\hline mean (SD) & $67.8(10.1)$ & $25.7(14.7)$ & $58.9(9.5)$ & 38.9 (14.7) & $67.5(14.3)$ & $56.0(14.9)$ & $57.2(8.9)$ & $48.8(10.1)$ & $49.6(6.7)$ & $32.4(9.1)$ \\
\hline range & $46.4-85.7$ & $0-57.1$ & $41.7-87.5$ & $8.3-83.3$ & $33.3-91.7$ & $16.7-75$ & $31.3-78.1$ & $34.4-78.1$ & $36.7-67.5$ & $15-57.5$ \\
\hline$p$ & \multicolumn{2}{|c|}{$<0.001$} & \multicolumn{2}{|c|}{$<0.001$} & \multicolumn{2}{|c|}{$<0.001$} & \multicolumn{2}{|c|}{$<0.001$} & \multicolumn{2}{|c|}{$<0.001$} \\
\hline $95 \% \mathrm{Cl}$ & \multicolumn{2}{|c|}{$(36.3-47.9)$} & \multicolumn{2}{|c|}{$(15.4-24.5)$} & \multicolumn{2}{|c|}{$(6.7-16.3)$} & \multicolumn{2}{|c|}{$(5.2-11.6)$} & \multicolumn{2}{|c|}{$(14.4-20.1)$} \\
\hline
\end{tabular}

obtained from patients after 12 hours of fasting. TSH levels were measured by immunoradiometric assay, using Kavoshyar (Iran-Tehran) kits. TSH tests were performed by Berthold-LB2111 unit gamma counter equipment. $\mathrm{Tg}$ and $\mathrm{TgAb}$ were measured using chemiluminescent immunoassay method by LIAISON analyzer (Germany). The mean coefficients of variation were below $10 \%$ for all these assays. The normal ranges were $0.3-0.5 \mathrm{U} / \mathrm{mL}$ for TSH, $5-25 \mathrm{ng} / \mathrm{mL}$ for $\mathrm{Tg}$ and $<116 \mathrm{U} / \mathrm{mL}$ for TgAb.

After blood testing, patients were asked to fill three questionnaires on $\mathrm{QOL}$, anxiety and depression. To determine the QOL, we used the World Health Organization (WHO) brief questionnaire [19]. This questionnaire assesses QOL using four dimensions of physical health, psychological, social relationships and environment, through items with five-point Likert scale; higher total score shows better QOL [20].

To assess depression, we used Beck Depression Inventory-second version (BDI-II) which determines the level of depression using its cognitive and physical symptoms [21]. It has 21 items with a four-point Likert scale. The score of $\leq 13$ shows that the patient is not depressed and the score of $\geq 14$ shows depression (14-19: mild depression, 20-28: moderate depression, $\geq 29$ severe depression). The score $\leq 4$ suggests that the patient denies depression, and very high scores suggest exaggeration of depression as well [21].

Finally, the hospital depression and anxiety scale (HADS) questionnaire was used to determine anxiety and depression [22]. This questionnaire is designed especially for somatically ill patients. It has 14 items, each item scored on a four-point Likert scale. The score of $\leq 8$ suggests the absence of anxiety or depression, and the score $>8$ shows presence of anxiety or depression [22]. All questionnaires were translated into Persian and validated previously. Patients were asked to fill out the questionnaires at both time points.

Patients' data including age, gender, marital status, grading and staging of tumor, TSH. Tg, TgAb, and the score of three questionnaires at two time points were all collected in a database. Cancer staging was performed based on the recent management guidelines for patients with thyroid nodules and DTC [2]. Data analysis was performed using simple t-test, paired t-test, Wilcoxon signed ranks test, and McNemar test using SPSS 18. P-value less than 0.05 was considered as significant.

\section{Results}

Twenty-nine patients were enrolled in the study, including 11 males and 18 females (37.9\% and $62.1 \%$ resp.), with mean age of 42.6 years (ranging from 16 to 68 years; SD: 14.9). Twenty-one patients (72.4\%) had T1 tumors and the rest had T2 tumors (27.6\%). Also, 19 patients $(65.5 \%)$ had stage I thyroid cancer, seven patients $(24.1 \%)$ stage II, and three patients (10.3\%) stage III. Eighteen patients (62.1\%) reported no stress factors which may affect their QOL, anxiety, or depression; however, 11 of them reported stress factors, such as immigration, spouse death and very low income. The mean TSH level at the first and second time point were 
Tab. 3. Comparison of BDI-II scores before and after levothyroxine withdrawal.

\begin{tabular}{|c|c|c|c|c|c|c|c|c|}
\hline & \multicolumn{2}{|c|}{ Not depressed } & \multicolumn{2}{|c|}{ Low } & \multicolumn{2}{|c|}{ Moderate } & \multicolumn{2}{|c|}{ Severe } \\
\hline & before & after & before & after & before & after & before & after \\
\hline n (\%) & 15 (51.7) & $2(6.8)$ & $8(27.5)$ & $1(3.4)$ & $6(20.6)$ & $6(20.6)$ & $0(0)$ & $20(68.9)$ \\
\hline $\mathrm{p}$ & \multicolumn{2}{|c|}{$\mathrm{p}<0.001$} & \multicolumn{2}{|c|}{$p<0.001$} & \multicolumn{2}{|c|}{$p<0.001$} & \multicolumn{2}{|c|}{$\mathrm{p}<0.001$} \\
\hline
\end{tabular}

Tab. 4. Comparison of HADS scores before and after levothyroxine withdrawal.

\begin{tabular}{|c|c|c|c|c|c|c|c|c|}
\hline & \multicolumn{4}{|c|}{ Anxiety } & \multicolumn{4}{|c|}{ Depression } \\
\hline & \multicolumn{2}{|c|}{ before } & \multicolumn{2}{|c|}{ after } & \multicolumn{2}{|c|}{ before } & \multicolumn{2}{|c|}{ after } \\
\hline & no & yes & no & yes & no & yes & no & yes \\
\hline n (\%) & $10(34.4)$ & $19(65.5)$ & $3(10.3)$ & $26(89.6)$ & $2(6.8)$ & $27(93.1)$ & $0(0)$ & $29(100)$ \\
\hline $\mathrm{p}$ & \multicolumn{4}{|c|}{$p<0.005$} & \multicolumn{4}{|c|}{$p>0.05$} \\
\hline
\end{tabular}

0.73 and $106.9 \mathrm{U} / \mathrm{ml}$, resp. $(\mathrm{p}<0.001)$, showing that all patients went through a hyperthyroidism condition. Tg and $\mathrm{TgAb}$ levels were also increased at the second time point. Results from blood tests are presented in Tab. 1.

Scores from WHOQOL-Bref questionnaire are demonstrated in Tab. 2 in four dimensions (D). As it is shown in the table, the mean scores for D1, D2, D3, and D4 before levothyroxine withdrawal were $67.8,58.9,67.5$, and 57.2 resp. These means decreased to 25.7 for D1, 38.9 for D2, 56 for D3, and 48.8 for D4 after one-month of levothyroxine withdrawal ( $p<0.001$ ). Table 3 shows results from BDI-II. At the first time point, 15 patients were not depressed and no one was severely depressed, while at the second time point, 20 patients were severely depressed. Wilcoxon signed rank test showed that the aforementioned difference is statistically significant ( $z$ : -4.523; $p<0.001$ ). Regarding HADS scores, 19 patients were anxious at the first time point, which increased to 26 cases at the second time point $(p<0.001)$. Also, 27 patients were depressed initially, which increased to 29 patients at the end of study $(p>0.05)$. These findings are summarized in Tab. 4.

\section{Discussion}

As discussed earlier, DTC patients need to discontinue their thyroid supplemental drug temporarily to perform WBS [2].
Some studies have suggested that this episode of hypothyroidism can have negative effects on patients QOL $[23,24]$. Also, other psychological aspects have been evaluated in previous studies, suggesting impairment of psychometric functionality in the hypothyroidism phase $[8,9]$.

The importance of QOL and other psychological aspects is also a topic of debate in all cancer patients, because of the chronicity of their disease and its nature [10]. Therefore, patients with DTC may experience decreased QOL, depression and anxiety because they have cancer [25], and these disorders may be exacerbated after levothyroxine withdrawal. It should be noted that these patients are considered cured and may not get enough attention for their QOL and general health status [14].

In our series, the mean TSH level before levothyroxine withdrawal was 0.73 , with a median of 0.20 which shows that most patients had suppressed TSH level, and the mean was increased to 106.9 which shows all patients were in the hypothyroidism phase at the second time point. Tg levels were measured at the first time point to see whether there are still thyroid remnants that produce $\mathrm{Tg}$. The mean of 20.4 for $\mathrm{Tg}$ with SD of 49.5 showed most patients did not have detectable levels of $\mathrm{Tg}_{\text {; }}$ however, normal ranges or high ranges were also reported in a small number of them. This shows that most cases had no remaining thyroid tissue. Tg mean was increased to 63.6 which is the result of increased level of TSH in patients and increased production of $\mathrm{Tg}$ by thyroid remnants consequently. High levels of $\mathrm{TgAb}$ can result in false lower results of $\mathrm{Tg}$ in the laboratory [26]. For better evaluation of $\mathrm{Tg}$ levels, $\mathrm{TgAb}$ levels were also measured, which showed a normal range at both time points suggesting that $\mathrm{Tg}$ results are not falsely lower than the real amount.

Regarding QOL, scores in all dimensions were significantly decreased at the second time point. This decrease was more tangible in the physical health dimension, followed by psychological dimension. Physical health dimension covers questions about activities of daily living, energy and fatigue, mobility, pain and discomfort, sleep and rest, and work capacity [20] and these items may be affected more by hypothyroidism symptoms. Dow et al. showed that HRQOL is decreased after levothyroxine withdrawal; however, they evaluated QOL using a newly designed tool for this purpose [14]. Same findings were confirmed in the study by Tagay et al., using standardized tools to evaluate QOL [8] and also by other similar studies [9,23,27-29]. Our study confirms the previous findings on impaired QOL 
during levothyroxine withdrawal, with more emphasis on physical health and psychological dimensions.

We found that patients get significantly depressed after one month of levothyroxine withdrawal. In our series, $51.7 \%$ of patients were not depressed at the first time point, and most of them became moderately or severely depressed at the second time point. Previous findings on this issue are various in different studies. Tagay et al. found no significant change in depression in the hypothyroidism phase [8]. In contrast, other studies have found deterioration of depressive symptoms in these patients after levothyroxine withdrawal $[9,30,31]$. Most previous studies have evaluated depression in long-term subclinical hypothyroidism, and few of them have investigated it in a short-term hypothyroidism. Our finding is consistent with most previous studies on depression in the hypothyroidism phase; however, we found more dramatic rise in BDI-II scores compared to previous studies. Reviewing results from HADS-depression showed a slightly higher, but not significant number of depressed cases after levothyroxine withdrawal. Based on HADS scores, 27 patients were classified as depressed at the first time point, increasing to all patients at the second time point. Results from HADS-depression seem not to be reliable, compared to BDI-II scores. The reason may be because of the difference of methods that these questionnaires employ to detect depression in patients.

Finally, we found that patients experience more anxiety at the second time point. These results are considerable from two aspects. First, number of anxious patients at the first time point was higher compared to the healthy Iranian population reported in previous studies [22]. This may suggest that DTC patients experience more anxiety even on therapeutic doses of levothyroxine and in euthyroid phase; however, this finding may not be reliable considering the lack of control group in our study. Second, the significant increase in anxiety scores after levothyroxine withdrawal suggests that they need to tolerate even more anxiety at this one-month period of hypothyroidism. Previous studies have reported diverse results on this subject. Tagay et al. showed that these patients experience more anxiety compared to the healthy population; however, they did not find any difference between anxiety scores before and after levothyroxine withdrawal [8]. Some other reports have also studied level of anxiety in DTC patients and found them more anxious, probably because of the subclinical hypothyroidism [32,33]. But, few studies have addressed this issue in short-term hypothyroidism. Cohen et al. and Botella-Carretero et al. found impaired psychometric impairment in these patients after short-term hypothyroidism which is consistent with our results $[7,9]$.

We had some limitations in this study: 1. we lack a control group of healthy patients to compare results at the first time point which limited us to evaluate the base scores of our cases; 2 . we had limited number of patients who could be included in the study; 3 . we were obliged to use questionnaires that are translated and validated into the Persian version, and because of that, these three questionnaires were chosen to cover $\mathrm{QOL}$, depression and anxiety. Unfortunately, we could not use a disease-specific QOL questionnaire because of the mentioned problem. Finally, this study was designed as cross-sectional, and we cannot suggest any causality accordingly.

In conclusion, we found decreased QOL in DTC patients after short-term hypothyroidism, especially in physical health and psychological dimensions. Also, we found that patients get significantly depressed after this period and experience more anxiety as well. Our findings suggest that an alternative method, such as using rhTSH, should be considered in these patients. Psychooncological support may also be useful for them during the short-term hypothyroidism; however, considering the reversibility of their symptoms supportive care can be more effective.

\section{Acknowledgement}

We want to thank the vice-chancellor for research and technology of Isfahan University of Medical Sciences for supporting and funding this project.

\section{Ethical approval}

All procedures performed in studies involving human participants were in accordance with the ethical standards of the institutional and/or national research committee and with the 1964 Helsinki declaration and its later amendments or comparable ethical standards.

\section{Informed consent}

Informed consent was obtained from all individual participants included in the study.

\section{References}

1. Sadjadi A, Nouraie M, Mohagheghi MA et al. Cancer occurrence in Iran in 2002, an international perspective. Asian Pac J Cancer Prev 2005; 6(3): 359-363.

2. Cooper DS, Doherty GM, Haugen BR et al. Revised American Thyroid Association management guidelines for patients with thyroid nodules and differentiated thyroid cancer. Thyroid 2009; 19(11): 1167-1214. doi: 10.1089/thy.2009.0110

3. Morris LG, Sikora AG, Tosteson TD et al. The increasing incidence of thyroid cancer: the influence of access to care. Thyroid 2013; 23(7): 885-891. doi: 10.1089/thy.2013.0045. 4. Chow SM, Law SC, Au SK et al. Differentiated thyroid carcinoma: comparison between papillary and follicular carcinoma in a single institute. Head Neck 2002; 24(7): 670-677.

5. Enyioha C, Roman SA, Sosa JA. Central lymph node dissection in patients with papillary thyroid cancer: a population level analysis of 14,257 cases. Am J Surg 2013; 205(6): 655-661.

6. Lee J, Yun MJ, Nam KH et al. Quality of life and effectiveness comparisons of thyroxine withdrawal, triiodothyronine withdrawal, and recombinant thyroid-stimulating hormone administration for low-dose radioiodine remnant ablation of differentiated thyroid carcinoma. Thyroid 2010; 20(2): 173-179. doi: 10.1089/thy.2009. 0187.

7. Cohen O, Dabhi S, Karasik A et al. Compliance with follow-up and the informative value of diagnostic whole-body scan in patients with differentiated thyroid carcinoma given recombinant human TSH. Eur J Endocrinol 2004; 150(3): 285-290.

8. Tagay S, Herpertz S, Langkafel M et al. Health-related quality of life, anxiety and depression in thyroid cancer patients under short-term hypothyroidism and TSHsuppressive levothyroxine treatment. Eur J Endocrinol 2005; 153(6): 755-763.

9. Botella-Carretero JI, Gal JM, Caballero C et al. Quality of life and psychometric functionality in patients with differentiated thyroid carcinoma. Endocr Relat Cancer. Soc Endocrinology 2003; 10(4): 601-610.

10. Crevenna R, Zettinig G, Keilani M et al. Quality of life in patients with non-metastatic differentiated thyroid cancer under thyroxine supplementation therapy. Support Care Cancer 2003; 11(9): 597-603.

11. Trijsburg RW, Van Knippenberg FC, Rijpma SE. Effects of psychological treatment on cancer patients: a critical review. Psychosom Med 1992; 54(4): 489-517.

12. Newell SA, Sanson-Fisher RW, Savolainen NJ. Systematic review of psychological therapies for cancer patients: overview and recommendations for future research. J Natl Cancer Inst 2002; 94(8): 558-584.

13. Dagan T, Bedrin L, Horowitz Z et al. Quality of life of well-differentiated thyroid carcinoma patients. J Laryngol Otol 2004; 118(7): 537-542.

14. Dow KH, Ferrell BR, Anello C. Quality of life changes in patients with thyroid cancer after withdrawal of thyroid hormone therapy. Thyroid 1997; 7(4): 613-619.

15. Dow KH, Ferrell BR, Anello C. Balancing demands of cancer surveillance among survivors of thyroid cancer. Cancer Pract 1996; 5(5): 289-295. 
16. Davis JD, Tremont G. Neuropsychiatric aspects of hypothyroidism and treatment reversibility. Minerva Endocrinol 2007; 32(1): 49-65.

17. Eustatia-Rutten CF, Corssmit EP, Pereira AM et al. Quality of life in longterm exogenous subclinical hyperthyroidism and the effects of restoration of euthyroidism a randomized controlled trial. Clin Endocrinol (Oxf) 2006; 64(3): 284-291.

18. Dow KH, Lafferty P. Quality of life, survivorship, and psychosocial adjustment of young women with breas cancer after breast-conserving surgery and radiation therapy. Oncol Nurs Forum 2000; 27(10): 1555-1564

19. The WHOOOL Group. The development of the World Health Organization quality of life assessment instrument (the WHOQOL). In: Orley J, Kuyken W (eds). Quality of life assessment: International perspectives. Heidelberg: Springer 1994: 41-57.

20. The WHOQOL Group. Development of the World Health Organization WHOQOL-BREF quality of life assessment. Psychol Med 1998; 28(3): 551-558.

21. Ghassemzadeh H, Mojtabai R, Karamghadiri N et al. Psychometric properties of a Persian-language version of the Beck Depression Inventory - second edition: BDI-II-PERSIAN. Depress Anxiety 2005; 21(4): 185-192.

22. Montazeri A, Vahdaninia M, Ebrahimi M et al. The Hospital Anxiety and Depression Scale (HADS): translation and validation study of the Iranian version. Health Qual Life Outcomes 2003; 1(1): 14

23. Schroeder PR, Haugen BR, Pacini F et al. A comparison of short-term changes in health-related quality of life in thyroid carcinoma patients undergoing diagnostic evaluation with recombinant human thyrotropin compared with thyroid hormone withdrawal. J Clin Endocrino Metab 2006; 91(3): 878-884

24. Pacini F, Ladenson PW, Schlumberger M et al. Radioiodine ablation of thyroid remnants after preparation with recombinant human thyrotropin in differentiated thyroid carcinoma: results of an international, randomized controlled study. J Clin Endocrinol Metab 2006; 91(3): 926-932.

25. Lee Jl, Kim SH, Tan AH et al. Decreased health-related quality of life in disease-free survivors of differentiated thyroid cancer in Korea. Heal Qual Life Outcomes 2010; 8 : 101. doi: $10.1186 / 1477-7525-8-101$.

26. Pacini F, Pinchera A. Serum and tissue thyroglobulin measurement: clinical applications in thyroid disease. Biochimie 1999; 81(5): 463-467.

27. Hoftijzer HC, Heemstra KA, Corssmit EP et al. Quality of life in cured patients with differentiated thyroid carcinoma. J Clin Endocrinol Metab 2008; 93(1): 200-203.

28. Duntas LH, Biondi B. Short-term hypothyroidism after Levothyroxine-withdrawal in patients with differentiated thyroid cancer: clinical and quality of life consequences. Eur J Endocrinol 2007; 156(1): 13-19.

29. Luster M, Felbinger R, Dietlein M et al. Thyroid hormone withdrawal in patients with differentiated thyroid carcinoma: a one hundred thirty-patient pilot survey on consequences of hypothyroidism and a pharmacoeconomic comparison to recombinant thyrotropin administration. Thyroid 2005; 15(10): 1147-1155

30. Ladenson PW, Braverman LE, Mazzaferri EL et al. Comparison of administration of recombinant human thyrotropin with withdrawal of thyroid hormone for radioactive iodine scanning in patients with thyroid carcinoma. N Engl J Med 1997; 337(13): 888-896.

31. Meier CA, Braverman LE, Ebner SA et al. Diagnostic use of recombinant human thyrotropin in patients with thyroid carcinoma (phase I/II study). J Clin Endocrinol Metab 1994; 78(1): 188-196.

32. Baldini IM, Vita A, Mauri MC et al. Psychopathological and cognitive features in subclinical hypothyroidism. Prog Neuropsychopharmacology Biol Psychiatry 1997; 21(6): 925-935.

33. Monzanil F, Del Guerra P, Caracciol N et al. Subclinical hypothyroidism: neurobehavioral features and beneficial effect of L-thyroxine treatment. Clin Investig 1993; 71(5): 367-371 